\title{
Francesca Calamita
}

\section{WELLINGTON 2013}

\section{Tastefulness}

\section{Fashion, Food, Lust and Domesticity in Matilde Serao's La virtù di Checchina (1884)}

"Wellington 2013" refers to a series of articles which developed out of papers presented at the conference "New Perspectives on Italian Gender Studies", held on 15 February 2013 at the University of Wellington in New Zealand.

\begin{abstract}
Throughout Western culture the relationship between women and food has often been seen as a metaphor for something else. From the biblical episode of Eve and the apple to postmodern society, women's eating habits have been perceived not only as natural acts of self-nourishment but also as a display of affection, sexuality and tendency to sin. Similarly, women's clothing style has been read as an instrument of self-expression and a key marker of gender identity over the centuries.

At the time of the Unification of Italy, neurology, psychiatry and gynecology supported by patriarchal ideology, explicitly identified women as naturally unbalanced beings. As a result, a rigorous diet was recommended to control their voracious feminine behaviour. Preparing meals for the family was synonymous with women's traditional disposition to take care of others; however, eating some dishes or abstaining from them was also seen as contributing to regulate female disorderly conducts. The corset, an important fashion statement of the time, has been seen as one of the means to control - physically and morally - women's unstable behaviour, their eating habits and sexuality, thus connecting the complex discourse on food to that on clothing.

The short story La virtù di Checchina (1884) by Matilde Serao (1856-1927) presents several narrative instances where food preparation for the family and the protagonist's obsession for fashion take centre stage; these passages are often coupled with the portrayal of the frustration Checchina experiences towards women's pre-established social role. With a humorous tone, Serao depicts the social constrictions and the cultural contradictions bourgeois women were facing at the time. By analysing Checchina's daily routine between the kitchen and the closet, I shall demonstrate that for the protagonist, the activities which involve food and clothing are synonymous with something else: a way to express her deepest feelings, communicate her emotional state and reject the repressive social role she must play in a complex socio-cultural context that promotes a fragile and asexual ideal of femininity.
\end{abstract}

The e-journal «altrelettere» is hosted at the URL: http://www.altrelettere.uzh.ch , in accordance with the Open Access Policy of the University of Zurich. Please cite this article as follows: Francesca CALAMITA, Wellington 2013 - Tastefulness: Fashion, Food, Lust and Domesticity in Matilde Serao's "La virtù di Checchina" (1884), in «altrelettere», 16.02.2015, DOI: 10.5903/al_uzh-28.

(C) This article is licensed under a Creative Commons Attribution 2.5. Switzerland (CC BY-NC-ND 2.5). Please read the license terms on the website: http://creativecommons.org/licenses/by-nc-nd/2.5/ch/deed.en 


\section{Protesting Against an Unjust Female Fate}

Marchesa Colombi (1840-1920), pseudonym of Maria Antonietta Torriani, a very well-known late nineteenth-century Italian writer and acclaimed expert on good manners, ${ }^{1}$ ends her 1885 novel, Un matrimonio in provincia, with a significant comment by Denza, the young and unfortunate protagonist: «Il fatto è che ingrasso» (COLOMBI 1885, 195). ${ }^{2}$ Earlier in the novel, she had been forced by the cultural constrictions imposed on fin-de-siècle Italian women to marry a fortyyear-old notary with whom she had three children. Denza was not in love with him, nor was she attracted to his physical appearance (marked by a monstrous wart on his forehead); however her stepmother reminded her that she was thirty years old, therefore she should accept his proposal in order to fulfill her female destiny. As Giuliana Morandini notes, at the end of Marchesa Colombi's novel, the protagonist's emotional and physical spheres come together in order to express her frustration (MORANDINI 1980, 16). Indeed, by gaining weight, Denza's body tries to communicate a nonverbal message, a protest against an unjust female fate that has trapped the protagonist into an unwanted life since her childhood. Putting on weight thus becomes for her a tool of communication and eating food is used as a way to compensate something else: an emotional filler for her empty existence. According to Susie Orbach, author of the 1978 best-seller Fat is a Feminist Issue and distinguished psychoanalyst, "The resulting fat has the function of making the space for which women crave» (ORBACH 1978, 25). Like a present-day compulsive eater, Denza tries to satisfy her needs by eating, thus masking her desires and frustrations. She reminds us of the same attitudes employed by Orbach's patients towards feelings and eating habits; indeed, like them, Denza «feel[s] entitled to demand what [she] want[s]» through her body (ORBACH 1978, 58). According to feminist scholars, such as Kim Chernin, Marylin Lawrence, Morag Macsween and Orbach, 3 eating disorders and troubled relationships with food are unconsciously adopted by women in order to say what they cannot express with words; eating disorders are self-destructive languages which, however, give them the opportunity to replace conventional verbal communication. 
In late nineteenth-century Italy, one of the few spheres where middle-class women could act relatively freely was the administration of the household, and therefore food was a main element of their daily routine. As Anna Colella demonstrates in Figura di vespa e leggerezza di farfalla (2003), bourgeois women were surrounded by nutrition-related tasks from an early age: from grocery shopping to table setting. Hence, it is not surprising to note that food was employed as a means of displaying affection, protest and anger. Italian women writers of late nineteenth and early twentieth century, such as Neera (1846-1918), Marchesa Colombi and Matilde Serao (1856-1927), often portray female protagonists who employ the nonverbal language of food as a powerful weapon to express their feelings, mirroring in their fiction its social meaning. For example Neera's Teresa (1886), the young and disappointed protagonist of the homonymous novel, and Marta, the main character of L'indomani (1889), 4 question their destiny through their sick bodies and poor appetite. In Serao's $L a$ virtù di Checchina (1884), alimentary discourse pervades the text, which in turn depicts middle-class Italian women's routine in the kitchen in detail. The short story is one of the richest narrative works of the nineteenth-century in terms of its portrayal of food and women's routine in the household; it thus provides an ideal text to explore bourgeois eating habits from a gendered perspective. Whilst in Neera's Teresa and L'indomani, for example, images of women's relationship with food appear, the number is much more limited than in La virtù di Checchina, where eating-related tasks take centre stage.

\section{Emotionally Unstable and Sexually Dangerous}

«Creature innocenti, delicate, spesso infantili, ma anche emotivamente instabili e sessualmente minacciose» (COLELLA 2003, 23), this is how Colella describes late nineteenth-century Italian middle-class women and their perception by the medical discourse of the time. Indeed, in late nineteenth-century Europe ideal middle-class femininity was embodied by the so-called "angel of the house": a delicate and fragile figure, with a pale complexion and whose socially approved duties were limited to household management: "una creatura tutta corpo (e 
soprattutto utero e nervi)", whose socially-approved weakness shapes her existence (COLELla 2003, 190-192). Moreover, physicians of the time suggested that women were influenced by their unbalanced feminine nature, therefore eating the right food was considered essential in order to improve their weak and nervous state: «il candido latte, le tenere verdure e i dolci più squisiti» were commonly considered the complements and supplements to women's fragile nature (COLELLA 2003, 23). Colella's monograph focuses on the eating regimen of Italian bourgeois women - that excluded red meat, spices as well as caffeinated or alcoholic drinks, perceived as men's territory 5 - and advice by magazines and manuals of good manners that often encouraged them to control their diets from an early age onwards. However, while women were bombarded with recommendations on how they should behave at the family table and act in public occasions, at the same time the patriarchal authority also urged them to become regine della casa and to learn how to nourish their children and husband every day from breakfast to dinner, thus giving food a multifaceted meaning. On the one hand, middle-class women were supposed to control and restrict their food intake, in line with the ideal femininity of the time; on the other hand, they were required to actively collaborate with their servants in order to plan meals and cook daily for other members of their family. As a result, eating more food than what was required was perceived as an inappropriate behaviour. ${ }^{6}$ Interestingly, Colella quotes the thoughts of a writer of the time regarding a lower-class bride, who was portrayed as gorging at her wedding reception: «grassa e rubizza, con indosso tutti i colori dell'iride e mezza bottega d'orefice, incoraggiata assiduamente con la voce e coi gomiti a mangiare, rispondeva sghignazzando 'sono piena non ne posso più'» (quoted in CoLELLA 2003, 154). This description contrasts deeply with the portrayal of Queen Margherita of Savoy, whose delicate manners and pleasant behaviour were regarded as appropriate. Indeed, according to Stephen Gundle, Margherita was not only the personification of «beauty, elegance, morality and [...] hygiene», but she also showed self-control by abstaining from eating food in public, exactly as the social norms and cultural ideologies of the late nineteenth century advised women to do (GUNDLE 2007, 
39).7 However, although food duties in the bourgeois family were managed by women, they were still considered massaie, while the art of cooking and jobs as chef were essentially male territories. According to Colella, manuals of good manners and domestic economy, as well as recipe books, were meant for female readers, while treatises on cooking were written by male experts for male experts. ${ }^{8}$ For example, Trattato di cucina, pasticceria moderna, credenza $e$ relative confettureria (1854) by Giovanni Vialardi was written «a vantaggio dell'arte dei suoi colleghi»; however, the author added a chapter or «"trattatello" whose title was "alle madri specialmente"» (quoted in CoLELLA 2003, 73-74). As Marchesa Colombi suggests in her manual of good manners: «La mamma non si mette a mangiare di nulla se prima non ha servito i suoi figlioli» (COLOMBI 200o, 14). A bourgeois woman in late nineteenth-century Italy was born to work in the kitchen and satisfy others' needs; food thus acquired a complex meaning: a symbol of the increasing richness among middle classes, synonymous of restriction and control but also an instrument to nourish - emotionally and physically - the family.

Matilde Serao is aware of the complex relationship between women, food, sexuality and morality, as well as the medical perception of typically female nervous-related diseases, such as hysteria and anorexia, in post-unified Italy; indeed, in a 1884 letter to Gegè Primoli, talking about her health, she states: «Una nevrosi allo stomaco: figuratevi, una nevrotica grassa!» (quoted in BANTI 1965, 98). As Anna Banti suggests, Serao's neurosis could be related to her pregnancy and her troubled relationship with Edoardo Scarfoglio, her future husband; however it is significant to note the Neapolitan writer's awareness of the medical and socio-cultural link between ideal femininity, nutrition, body shape and psychopathologies which recalls Colella's analysis.

\section{Regulating Women's Disorderly Tendencies: the Corset}

In nineteenth-century Europe the corset, a very popular fashion undergarment, was related to bourgeois women's eating habits. 9 The corset was perceived not only as an essential fashion piece, but also as one of the instruments to regulate 
women's disorderly tendencies, similarly to food: «an ever present monitor», as suggested in a 1878 advertisement (quoted in BORDO 2003, 162). In Victorian England a woman without a corset was considered a prostitute, a feminist or a dress reformer (BAYLES KORTSCH 2009, 56). Choosing not to wear a corset was seen as an imitation of indecorous sexual behaviour and moral looseness, therefore middle-class women, traditionally perceived as asexual angels of the house, were required to use it. Interestingly, Christine Bayles Kortsch reminds us that women who laced their corsets too tightly fell in the category of those who «arouse impure desires»; however the word "loose", which implies a negative connotation, comes from the discourse on corsetry and is related to the tightness of their laces: prostitutes, indeed, did not usually wear them (BAYLES KORTSCH 2009, 56). Colella reminds us that in the early twentieth century, the well-known Italian magazine «La donna» published numerous articles on this subject; moreover opinions on the corset were very diverse, often leading to further discussions on the physiological consequences of wearing this garment; for example, Donna Clara and Dottor Napione encouraged their readers to eat lights meals in order to be able to wear the corset (COLELLA 2003, 147). The patriarchal society of the time imposed on women a fashion garment to control their naturally unstable behaviour, yet wearing clothes and accessories was still a powerful weapon to express themselves; as in the case of food, women learned to use the corset to express themselves. ${ }^{10}$ In Diane Crane's words: «on the one hand, styles of clothing can be straitjacket, constraining (literally) a person's movements and manners, as the case for women's clothing during the Victorian era. [...] Alternatively, clothing can be viewed as a vast reservoir of meanings that can be manipulated or reconstructed so as to enhance a person's sense of agency» (CRANE 2000, 2). ${ }^{11}$

One of the opening scenes of the renowned film Gone with the Wind (1939), ${ }^{12}$ which is set in the second half of the nineteenth-century, is particularly appropriate to represent the relationship between middle-class women, food and fashion in the late nineteenth century. After being tightened in a corset by her housemaid to attend a party, Scarlett (Vivien Leigh), the young protagonist, 
refuses to eat her breakfast despite Mammy's (Hattie McDaniel) suggestion. With a motherly tone, her housemaid attempts to explain to her that a proper lady should not eat in public; therefore, she should eat something before the party in order to show self-control at the event. After putting on a white and green dress, a large hat and a matching belt, Scarlett replies to Mammy that Ashley (Leslie Howard), the man she loves, likes women who show their appetite in public occasions. Changing her register suddenly, the servant replies wisely that what men say and what men think are not exactly the same; indeed, he has not yet asked Scarlett to become his wife. As soon as the young and deluded protagonist hears this sentence, she devours her breakfast thus expressing through food her mixed feelings and frustration towards her social role: «Why do I have to get so silly to find a husband?»

\section{Food and Feelings: Checchina's Routine in the Kitchen}

This multifaceted discourse on food, fashion and feelings is depicted in a short story by Serao ${ }^{13}$ La virtù di Checchina, which portrays in humorous tones the lifestyle of middle-class Italian women between the nineteenth and twentieth centuries, when female identity was being shaped within national culture. Serao also writes about food in Il ventre di Napoli where she describes Neapolitan eating habits in the nineteenth century. The writer focuses in particular on lower classes' experiences of food and the art of creating meals within a very limited daily budget (SERAO, 1998 49-53). This detail, however, also recalls Checchina's daily routine: despite her middle-class status, she is on a budget both to satisfy her husband's culinary requests and to save in order to buy herself new dresses and accessories to raise his attention towards her. Food and its related activities also play an important part in other works by Serao, such as Il paese di cuccagna (1891), Suor Giovanna della croce (1901) and La ballerina (1901), in which it gains an anthropological meaning which goes further than simple nutrition (VALENTINI 2009). It is only in La virtù di Checchina, however, that she portrays images of food from a gendered perspective. 
Checchina's monotonous daily routine is narrated in a passage where she appears busy planning lunch for an important guest, il marchese Ugo D’Aragona, who could potentially bring new clients to her husband's medical centre:

Ora questo marchese veniva a pranzo - ed ella non sapeva che dargli da mangiare a questo nobile [...]. Avevano un servizio di piatti solo per sei persone, [...] sarebbe bastato? E l'insalata, poiché ci vuole, l'insalata in pranzo, dove l'avrebbe messa? Ecco, gli si potevano dare gli gnocchi col sugo di carne [...]. Poi sarebbe venuta la carne col contorno di patate, cotte nel sugo: poi, un piatto di pesce fritto [...] E l'arrosto, l'arrosto ci voleva [...] bisognava dargli anche il piatto dolce. [...] La torta con la conserva di amarena? [...] E il caffè si dà in tavola, non è vero, dopo che si è sparecchiato? (SERAO 1985, 216-17)

Checchina wants to show her husband's acquaintance that she is a perfect wife by organising and preparing a delicious meal as she is supposed to do; however, she points out in several passages that she would like to be considered an ideal partner not only for her domestic skills, but also for her elegance and pleasant manners. Nevertheless, Checchina's husband often reminds her of her traditional role as domestic goddess. For instance, in a scene where Checchina expresses her interest in buying a new dress, the doctor replies firmly:

Scusa, perchè te lo dovrei fare? Quelli che hai non ti bastano? Sono tanti! Hai da far la bellina per me? Checca mia, oramai ti conosco, ti so molto, e questo civettio non serve più. (SERAO 1985, 227)

Checchina is very frustrated by this outcome and after a while she starts to complain again, but in return her husband immediately reminds her of her role as a wife and her responsibilities in the household:

- Alle solite, neh, Checca mia? Sarebbe meglio pensassi alla minestra di cicoria, che Susanna ha dimenticato di metterci una cotenna grassa di maiale. E dire che lo sai quanto mi piace la cotenna!

- Come ti pare questo cappello?- chiese lei.

- E che vuoi che io ne capisca, dei vostri capricci femminili? [...]

- Ora non è tempo di far cotesto, Checca - esclamò il dottore, con la sua voce grossa ora si mangia. (SERAO 1985, 229)

Fixing her old hat should not be read only as an act of vanity on Checchina's part, but, as importantly proposed by Laura Anne Salsini in Gendered Genres, as 
a «metonymic symbol of her own re-fashioning» (SALSINI 1999, 38-39). Indeed, the scholar argues that Totò's negative comments on Checchina's hat are an indirect attempt to suggest to his wife not to change her conventional role in the family environment; in other words, not to swap her submissive identity for a more self-confident one (SALSINI 1998, 39). Altering her hat thus becomes a significant metaphorical gesture that allows Checchina to transform her frustrating daily existence in the house and her suffocating matrimonial routine. Significantly, at the end of a similar discussion during a meal, Checchina, irritated by her husband's behaviour, sits down at the table «rompendo le cortecce vuote delle caldarroste in minuti pezzettini (SERAO 1985, 230-31)»; with this simple gesture, Checchina communicates her frustration towards her marriage by employing food as an instrument of communication. The food she manipulates every day in order to make her husband happy and to fulfill her social role as a perfect wife becomes the main instrument of her inner rebellion, a powerful weapon to express her deepest feelings. Metaphorically, Checchina's lifestyle is shaped by her husband's rules which, like a corset, force her to behave as a perfect angelo del focolare. Totò is unable to understand Checchina's messages, both verbal and unidiomatic, furthermore he completely ignores Checchina's attempt to question their relationship. He perceives her requests as extravagant and he often reminds her of her matrimonial duties. Similarly to Marchesa Colombi's Denza and Susie Orbach's patients, Checchina expresses herself through alternative instruments of communication; indeed not only she is not allowed to communicate her innermost thoughts to Totò but even when she tries to do so, her husband does not understand. Checchina is looking for affection in their relationship; however the doctor acts as an intimacy-disabler, who is unable to understand his wife's deepest needs. Salsini suggests that in Serao's narrative works male characters are often unable to look into the female psyche; this technique is often used by the Neapolitan writer to question the model of the bourgeois marriage by portraying protagonists who are trying to escape from their already established social destiny, however their messages are not decoded by their partners (SALSINI 1999, 36). In this narrative scene, food 
acquires a double meaning: it is an instrument to feed the other members of her family and a weapon of the protagonist's inner rebellion: a complex way to untie her "social corset".

\section{Isolina: an Alternative Femininity}

To escape her marital frustration, Checchina thinks about her physical appearance and tries to imitate her friend Isolina who spends a huge amount of money to make herself look beautiful. However, she is not brave enough to break her husband's rules; indeed she often ends up mending her old clothes instead of buying new ones. During a reunion, Isolina tries to convince Checchina to change her hairstyle along with her boring husband:

- Ti si rivede finalmente core mio! [...] Sei più bella più colorita: peccato che tutto questo si perda, con quello scemo di Totò che non capisce nulla! E perché porti la frangetta di capelli sulla fronte che nessuno usa più?

- Ma... è più comoda [...]

- Che, che! Si compra un ferro per arricciare i capelli, si mette un carboncino acceso in uno scaldino e si fanno i riccioli, ogni mattina. Ecco come me. [...]

- Susanna non sa fare tutto questo - rispose Checchina ostinatamente. (SERAO 1985, 212-13)

After her meeting with Isolina, Checchina returns to her usual routine. While she is busy preparing the menu for the marquis, the protagonist suddenly asks her servant Susanna: 14 «Li sapresti fare i riccioli sulla fronte? [...] Come quelli di Isolina» (SERAO 1985, 218). With this simple sentence, Checchina communicates her unhappiness towards her role in the family. Changing her hairstyle would mean becoming more like the glittery Isolina who is socially free (SALSINI 1999, 37). ${ }^{15}$ Isolina has many lovers and fashionable clothes while Checchina must follow her husband's rules and spend her life between the kitchen and the dining room, obsessed by thoughts of escaping her daily routine. ${ }^{16}$ There are no passages in the short story where Serao's protagonist is tightened up in a corset like Scarlett in Gone with the Wind, however she is forced into playing the role that the patriarchal society imposes on her. According to Malcom Barnard, «fashion and clothing simply reflect an already existing sex and gender identity» 
(BARNARD 2004, 17). Checchina has been confined to the kitchen; she has not enough courage to ask Totò for more money to buy new garments, however she dreams of new hats and dresses all the time: «Si rassegnava, soffrendo in silenzio, pur di non udire quella voce grossa che calcolava il valore di un soldo e gliene rinfacciava la spesa [...]» (SERAO 1985, 231). On the contrary, Isolina has numerous debts to satisfy her fashion obsession:

- Questo cappello è nuovo nevvero?

- Sì nuovo: figurati non l'ho ancora pagato. La Coppi mi conosce, mi aspetterà. Avevo dei quattrini ma ho dovuto comprare le scarpette.

- Queste qui, lucide, dorate?

- Queste qui core mio: nientemeno costano sedici lire [...] ma vedi che tacco che impuntura, che punta sottile! (SERAO 1985, 233)

Isolina's relationship with clothes, however, cannot fall only into the category of self-expression: it is also a way to please her lovers. If Checchina, as a perfect wife, is required to cook for Totò and in doing so to fulfill her social role as regina della casa, Isolina, as a perfect mistress, is required to buy new clothes for her suitors and in doing so to fulfill her social role as lover. As Salsini notes, Isolina is synonymous with «carefree independence», while Totò embodied the «repressive bourgeoisie» (SALSINI 1999, 36). Checchina, indeed, is unable to overcome the social norms of the time and to meet secretly the fascinating marquis at his garçonnière; in front of his residence, she decides not to enter, thus sharing with Isolina and Gustave Flaubert's Emma Bovary, the nineteenth-century fictional mistress par excellence, only the thrills of potential lust and adultery. ${ }^{17}$ Not only she is not brave enough to betray her husband but she also does not have the right accessories to do it:

Checchina si mise a piangere. Ella non aveva né le scarpette dorate, né i fazzoletti di batista, né il manicotto né lo spillo a ferro di cavallo, né l'orologio. Piangeva perché non aveva niuna di queste cose che servono all'amore. (SERAO 1985, 277)

Divided between Isolina's fashionable independence and Totò's repressive attitude, Checchina is unable to solve this socio-cultural dilemma and she remains in the kitchen without a lover and without new clothes. In doing so, 
Checchina saves her virtue and accomplishes her pre-established social role of the angel of the house, as a perfect bourgeois wife should have done. She is not a sinner, as her friend Isolina, but a "donna-madonna" who is unable to push the socio-cultural boundaries any further.

As Joanne Entwistle suggests, the meaning of a particular garment changes over the years; if we consider the corset, for example, in the nineteenth century it was synonymous with women's social and moral constriction imposed by the patriarchal authority, but in postmodern times it is associated not only with seduction but also with sadomasochist practices and pornography (ENTWISTLE 2000, 195-200). It was considered traditional in women's fashion after the Unification of Italy and it is now perceived as an almost bizarre piece of underclothing. ${ }^{18}$ Many scholars have pointed out that in the postmodern era the corset is still synonymous with women's social constrictions, indeed in everyday life it has been replaced by diets which regulate women's behaviour and show their self-control once again. ${ }^{19}$ Women do not use daily a corset anymore but wear high heels and extremely tight dresses that are able to show their selfcontrol, similar to late nineteenth-century social constrictions imposed on them; however despite socio-cultural obligations on how to dress, clothing is still a powerful code to express oneself and to mark gender identities, exactly as it was for Checchina in late nineteenth-century Italy. Similarly, some dishes and drinks which were used to be considered "masculine" are consumed largely by women today; for instance, red meat, soft and alcoholic drinks. However, food advertisements often emphasise the complex relationship between women, food and sexuality. Light and healthy food is frequently promoted by glamorous angels of the house, who look after their families and their own body, while naughty food - in particularly I am referring to desserts and ice-cream - is advertised by women who recall, with their provocative and aggressive approach, lust and moral negligence; ${ }^{20}$ as Susan Bordo suggests, greediness and voracity are explicitly related to sexual hunger (BORDO 2006, 110). Interestingly she adds that women are allowed «food lust» only when they are pregnant (BORDO 2006, 100), in other words, when they are already feeding someone else and therefore they 
can justify their disobedient behaviour. Despite social and cultural equality, women are still responsible for family meals, however while society now allows them to theoretically eat whatever they want, Orbach remind us that «women must hold back their desires for the cake they bake for others [...]. Diet, deprive, deny is the message women receive» (ORBACH 1993, 41). Both food and fashion can be read as powerful instruments of communication, but paradoxically they have also been employed by patriarchal authority to control women through history, thus revealing themselves to be both extremely empowering and extraordinarily disempowering tools. ${ }^{21}$

\section{Conclusion}

In her recent Matilde Serao: una scrittura quotidiana, Rossana Melis highlights that the writer supports «le donne d'ingegno» in her fictional and non-fictional writings (MELIS 2014, 125). Women, in other words, who were aware of their social role and who contributed to discussing it. As several critics have pointed out, and as Katharine Mitchell (2013) has recently discussed, Serao belongs to that group of late nineteenth-century women writers, along with Neera and Marchesa Colombi, who do not describe themselves as protofeminist, and yet who, in their fictional writing, often question the role of the angelo del focolare. Among Serao's numerous fictional characters, Checchina is one of those characters who discusses her socio-cultural role and predestined fate as a woman. Unable to overcome the sociocultural boundaries that are imposed upon her, she instead finds a way to question them with the very same instruments that were given to her by patriarchal society and Catholic ideology in order to accomplish her cultural task of "donna" and "Madonna". As many other nineteenth-century heroines, such as Marchesa Colombi's Denza and Neera's Marta, the outcome of their struggles may be almost invisible, yet they nonetheless attempted to change their pre-assigned destiny. Checchina's attitude towards food precisely depicts this almost imperceptible change: food is not only a need but also a source of emotional nurturance as well as a synonym of rebellion against the rules imposed by patriarchal society. It identifies her as a caregiver for Totò, but it is also the 
instrument of protest against her repressive social role and the bourgeois identity in the late nineteenth-century. Indeed, in Serao's short story food is one of the few tools of self-expression available to women in a society which claimed them as natural "food givers". Similarly, Checchina's love for clothing is a way to escape her marital routine and to reach Isolina's social freedom, but at the same time she is tightened by her husband rules that act as a moral corset. With an entertaining tone, in La virtù di Checchina Serao questions Italian female identity and the cult of domesticity at the turn of the twentieth century, employing women's tools par excellence. 


\section{Notes}

1 In 1877 Marchesa Colombi wrote a very successful conduct book: La gente per bene (Novara, Interlinea, 2000). Michela De Giorgio, in her essay on Italian women's experience from the Unification to the present, refers to her as «la pioniera del genere normativo» DE GIORGIO 1992, p. 46.

2 The digital version of the book is available on the website of the Biblioteca Nazionale Braidense, project Di.Re. www.braidense.it/dire/matrimonio/matrimonio.html (last accessed 5.08.2013), where many narrative works by late nineteenth-century Italian women writers are available, such as a selected number of those by Neera (1846-1918) and Matilde Serao (18561927).

3 In particular I am referring to Kim CHERNIN, The Hungry Self: Women, Eating and Identity, London, Virago, 1986; Marilyn LAWRENCE, The Anorexic Experience, London, Women's Press, 1984; Morag MacSweEn, Anorexic Bodies: A Feminist and Sociological Perspective on Anorexia Nervosa, London, Routledge, 1993; Susie ORBACH, Hunger Strike: The Anorectic's Struggle as a Metaphor for Our Age, London, Penguin, 1993) and EAD., Fat is a Feminist Issue: The Anti-Diet Guide to Permanent Weight Loss, New York, Paddington Press, 1978.

4 For an analysis on food, gender and anorexia as an unidiomatic instrument of communication in Neera's narrative production see the book chapter Discussing Women's Social Role through Paradoxical Behaviours: Starvation and Self-empowerment in Neera's 'Teresa' (1886) and 'L'indomani' (1889), in Gendering Commitment: Re-thinking Social and Ethical Engagement in Modern Italian Culture, edited by Alex Standen and Clare Watters, Cambridge, Cambridge Scholar, forthcoming; for a further analysis on the meaning of food and its relationship with Catholic ideology in Neera's short story Uno scandalo see my article: Storytelling and Female Eating Habits at the Turn of the Twentieth Century: Italo Calvino's 'Zio Lupo' and Neera's 'Uno Scandalo', in "AUMLA, Special Issue, Refereed Proceedings of the 2011 AULLA Conference: Storytelling in Literature, Language and Culture», (2012), April, pp. 67-75. On illness as a way of communication in Neera's Teresa and L'indomani see also Katharine MitCHELl, Neera's Refiguring of Hysteria as Nervosismo in 'Teresa' (1886) and 'L'indomani' (189o), in Rethinking Neera, edited by Mitchell and Catherine Ramsey-Portolano, supplement to «The Italianist», vol. 30, n. 3 (2010), pp. 101-122.

5 Joan Jacobs Brumberg, who has extensively studied the notion of femininity in relation to eating habits in Victorian England, suggests similarly that «[b]ourgeois society generated anxieties about food and eating-especially among women. Where food was plentiful and domesticity venerated, eating became a highly charged emotional and social undertaking. Displays of appetite were particularly difficult for young women who understood appetite to be both a sign of sexuality and an indication of lack of self-restraint. Eating was important because food was an analogue of the self». Joan Jacobs BRUMBERG, Fasting Girls. The Emergence of Anorexia Nervosa as a Modern Disease, Cambridge, Harvard University Press, 1988, pp. 178-79.

6 The same perception applied to alcoholic drinks. "Una donna anche se vecchia non farà mai un brindisi a tavola [...] il costume [...] non permette gli atti virili come il fumare, lo schermire ed il vociare in pubblico». Quoted in CoLELLA 2003, pp. 155-57.

7 On the notion of ideal beauty at the end of the nineteenth century, see in particular the chapter The Blonde Aura of Queen Margherita, pp. 33-57 in GuNDLE 2007.

8 On the perception of men as chef and women as massaie, see also Maria Giuseppina Muzzarelli e Fiorenza TARozzi, Donne e cibo: una relazione nella storia, Milano, Bruno Mondadori, 2003, p. 134.

9 For a detailed history of the corset, see Valerie StEEL, The Corset: A Cultural History, Yale, Yale University Press, 2004.

10 Fred Davis in Fashion, Culture and Identity remind us that «Through clothing people communicate some things about their persons, and at the collective level, this results typically in locating them symbolically in some structured universe of status claims and life-style attachments». Fred DAvis, Fashion, Culture and Identity, Chicago, Chicago University Press, 1994, p. 4. 
11 In particular, see the chapter "Women's clothing behavior as nonverbal resistance", pp. 99139.

12 Victor Fleming, Gone with the Wind, produced by David O. Selznick, released on 15 December 1939, Metro-Goldwyn-Mayer, U.S.A.

13 Serao was born in Patras in 1856 and moved to Naples in 1872 with her family; previously her father left Italy during the anti-Borbons disorders of 1848. She gained a diploma for teaching and married Edoardo Scarfoglio; together they established «Il corriere di Roma» and «Il corriere di Napoli». After the end of their relationship, Serao set up «Il Giorno», a direct rival of «Il mattino» that was owned by her former husband. She died in 1927. Anna Banti wrote a detailed analysis on Serao's works, private and public life. See, Anna BANTI, Serao, Torino, Unione Tipografica Editrice Torinese, 1965. See, also Sharon WooD, Italian Women's Writing (1864-1990), London, The Athlone Press, pp. 40-57.

14 Susanna often judges Checchina's behaviour and she keeps a close eye on her daily routine. Silvia D'Amico calls her «una begina collerica che le incute suggestione». Silvia D'Amico, Una Bovary a Roma: note su «La virtù di Checchina» di Matilde Serao, in Lingua, Cultura e Testo: Miscellanea di studi francesi in onore di Sergio Cigada - Volume II, tomo I, edited by Enrica Galazzi e Giuseppe Bernardelli, Milano, Vita e Pensiero, 2003, pp. 285-97 (p. 285).

15 D'Amico gives to Isolina an appropriate adjective by addressing her as «spumeggiante»: D'AMICO 2013, 265.

16 Following Umberto Eco (1979) suggestions on code and social "arrangements", Davis suggests that «clothing styles and fashions [...] constitute something approximately to a code». DAVIS 1994, 5 .

17 For an analysis on the influence of Flaubert in Serao's writing and a comparison between Checchina and Emma, see D'AMICO 2003.

18 The case of the corset is particularly debated and controversial; in postmodern times has become the symbol of a further controversial practice, the new burlesque, a performing art inspired to the late nineteenth and early twentieth century comedy cabaret, that, however, involves the removal of clothes in its 1990s-2000s version. In The Happy Stripper: Pleasures and Politics of the New Burlesque, Jacki Willson reminds us that «the corset, an erotic accessory that had been formerly equated by feminists with antifeminists or prefeminist sexist ideas and attitudes, became a post-feminist symbol of women's sexual freedom». The burlesque dancer, indeed, is aware of her sexual objectification as a woman who is stripping on stage, however in her performance she questions it with a humorous tone. Nevertheless, it should be noted that the dancers are stripping for their audience and the voyeurs may not perceive their acts as self-empowering but merely as sexual. As Willson puts it, «without being coupled with an ironical, satirical and effective questioning of sexual power, erotic display risks falling immediately back into unchallenging stereotypical 'off the shelf' - vulnerable, silent and fake». The performers often wear corsets as a part of their stage costume; this piece of underclothing could be both an instrument of social freedom and cultural constriction. WILLSON 2008, 145.

Furthermore, the display of a naked body is not seen any more as a synonymous with sexual availability but rather as the ability to be in control of the body and its image, as Diane Crane notes referring to Madonna's music videos in the 1980s-1990s (CRANE 2000, 158). In accordance with Natasha Walter, in this article I am not judging women over their choices and interests; however it should be pointed out that an increasing number of them has chosen as hobby or work a performance that is linked to stripping, sex work and pole dancing. Even if it includes the rhetoric of empowerment, the new burlesque «serv[es] up misogyny with a tasteful package of feathers. [...]. It is a clear remainder that «our culture is dedicated to producing an endless conveyor-belt of women who are there for men's sexual convenience». Natasha WALTER, Living Dolls: the Return of Sexism, London, Virago, 2010, pp. 41-45 and p. 63 .

19 See for example VANDEREYCKEn e VAN DETH 1995, 163 and 253. See also Bordo 2003, 163.

20 See CALAMiTA 2014, pp. 1-13. 
21 For an overview on the relationship between fashion, feminism and femininity in postmodern times, see Linda M. ScOTT, Fresh Lipstick: Redressing Fashion and Feminism, New York, Palgrave Macmillan, 2006.

\section{Bibliography}

ARSLAN 1998

Antonia ARSLAN, Dame, galline e regine: la scrittura femminile italiana fra '8oo e ' 9oo, Milano, Guerini Studio, 1998.

ARTUSI 2010

Pellegrino ARTUSI, La scienza in cucina e l'arte di mangiar bene, a c. di Alberto Capatti, Milano, BurRizzoli, 2010.

BANTI 1965

Anna BANTI, Serao, Torino, Unione Tipografica Editrice Torinese, 1965.

BARNARD 2004

Malcom BARNARD, Fashion as communication. Second edition, London, Routledge, 2004.

BORDO 2003

Susan Bordo, Unbearable Weight: Feminism, Western Culture, and the Body, Berkeley and Los Angeles, University of California Press, 2003.

BRUMBERG 1998

Joan Jacobs BRUmberg, Fasting Girls: The History of Anorexia Nervosa, Cambridge, MA, Harvard University Press, 1988.

CALAMITA 2014

Francesca CALAMITA, Voracious Dolls and Competent Chefs: Negotiating Femininities and Masculinities in Italian Food Advertisement of the 1990s-2010s, in «Gender/Sexuality/Italy», 1, May 2014, pp. 1-13.

CALAMITA 2013

«Neera», voce a c. di Francesca Calamita nel sito web de L'enciclopedia delle donne, www.enciclopediadelledonne.it (27.02.2014).

CALAmita 2012

Francesca CALAmitA, Storytelling and Female Eating Habits at the turn of the Twentieth Century: Italo Calvino's "Zio Lupo" and Neera's "Uno Scandalo", in "AUMLA, Special Issue, Refereed Proceedings of the 2011 AULLA Conference: Storytelling in Literature, Language and Culture», April 2012, pp. 67-75.

CHERNIN 1986

Kim CHERNIN, The Hungry Self: Women, Eating and Identity, London, Virago, 1986. 
COLELLA 2003

Anna COLELLA, Figura di vespa e leggerezza di farfalla. Le donne e il cibo nell'Italia borghese di fine Ottocento, Firenze, Giunti, 2003.

COLOMBI 2000

Marchesa CoLOMBI, La gente per bene, Novara, Interlinea, 2000.

CRANE 2000

Diane CRANe, Fashion and its Social Agendas: Class, Gender and Identity in Clothing, Chicago, The University of Chicago Press, 2000.

D’AMICO 2003

Silvia D'Amico, Una Bovary a Roma: note su "La virtù di Checchina" di Matilde Serao in Lingua, Cultura e Testo: Miscellanea di studi francesi in onore di Sergio Cigada, a c. di Enrica Galazzi e Giuseppe Bernardelli, Milano, Vita e Pensiero, 2003, vol. II, tomo I, pp. 285-97.

DAVIS 1994

Fred DAVIS, Fashion, Culture and Identity, Chicago, Chicago University Press, 1994.

DE GIORGIO 1992

Michela DE GIORGIO, Le italiane dall'unità ad oggi. Modelli culturali $e$ comportamenti sociali, Roma-Bari, Laterza, 1992.

ENTWISTLE 2000

Joanne ENTwISTLE, The Fashioned Body: Fashion, Dress and Modern Social Theory, Cambridge, Polity Press, 2000.

GUNDLE 2007

Stephen GundLe, Bellissima. Feminine Beauty and the Idea of Italy, New Haven and London, Yale University Press, 2007.

BAYLES KORTSCH 2009

Christine BAYles KorTSCH, Dress Culture in Late Victorian Women's Fiction. Literacy, Textiles and Activism, Surrey, Ashgate Publishing Company, 2009.

KRUGOVOY SILVER 2002

Anna KRUgovoY SILVER, Victorian Literature and the Anorexic Body, Cambridge, Cambridge University Press, 2002.

LAWRENCE 1984

Marylin LAWRENCE, The Anorexic Experience, London, Women’s Press, 1984.

MACSWEEN 1993

Morag MacSween, Anorexic Bodies: A Feminist and Sociological Perspective on Anorexia Nervosa, London, Routledge, 1993.

MCEACHERN 1998

Patricia MCEACHERN, Deprivation and Power: The Emergence of Anorexia Nervosa in Nineteenth Century French Literature, Westport, Greenwood Press, 1998. 
MELIS 2013

Rossana Melis, Matilde Serao: una scrittura quotidiana, in Di generazione in generazione. Le italiane dall'Unità ad oggi, a c. di Maria Teresa Mori, Alessandra Pescarolo, Anna Scattigno e Simonetta Soldani, Roma, Viella, 2014, pp. 121-135.

MICHIE 1987

Helena MichIE, The Flesh Made Word, New York, Oxford University Press, 1987.

MiTCHELL 2010

Katharine MitchelL, Neera's Refiguring of Hysteria as Nervosismo in 'Teresa' (1886) and 'L'indomani' (1890), in Rethinking Neera, eds. Katharine Mitchell and Catherine Ramsey-Portolano, supplement to «The Italianist», vol. 30, n. 3 (2010), pp. 101-122.

MITCHELL 2013

Katharine MitchelL, Italian Women Writers. Gender and Everyday life in Fiction and Journalism, 1870-1910, Toronto, University of Toronto Press, 2013.

MORANDINI 1980

Giuliana MorANDINI, La voce che è in lei. Antologia della narrativa femminile tra '8oo e '9oo, Milano, Bompiani, 1980.

MUZZARELLI e RE 2005

Il cibo e le donne nella cultura e nella storia. Prospettive interdisciplinari, a c. di Maria Giuseppina Muzzarelli e Lucia Re, Bologna, Clueb, 2005.

MUZZARELLI e TAROZZI 2003:

Maria Giuseppina MuZZARELli e Fiorenza TAROZZI, Donne e cibo: una relazione nella storia, Milano, Bruno Mondadori, 2003.

NEERA 1995

NeERA, Teresa, Lecco, Periplo Edizioni, 1995 (1886).

NEERA 1997:

NEERA, Lydia, Lecco, Periplo Edizioni, 1997 (1887).

NEERA 1981:

NEERA, L’indomani, Palermo, Sellerio Editore, 1981 (1889).

ORBACH 1978

Susie Orbach, Fat is a Feminist Issue: The Anti-Diet Guide to Permanent Weight Loss, New York, Paddington Press, 1978.

ORBACH 1993

ORBACH, Hunger Strike: The Anorectic's Struggle as a Metaphor for Our Age, London, Penguin, 1993. 


\section{SALSINI 1999}

Laura Anne SALSINI, Gendered Genres: Female Experiences and Narrative Patterns in the Works of Matilde Serao, Cranbury, London and Mississauga, Associated University Press, 1999.

SERAO 1985

Matilde SERAO, La virtù di Checchina, in EAD., Il romanzo della fanciulla, Napoli, Liguori Editore, 1985, pp. 216-56.

SERAO 1989

Matilde SERAO, Il ventre di Napoli, Napoli, Adriano Gallina Editore, 1988.

SERAO 2006

Matilde SERAO, Checchina's Virtue, trans. by Tom Kelso, in Writing to Delight: Italian Short Stories by Nineteenth-Century Women Writers, ed. Antonia Arslan and Gabriella Romani, Toronto, University of Toronto Press, 2006, pp. 19-57.

SCOTT 2006

Linda M. ScOTT, Fresh Lipstick: Redressing Fashion and Feminism, New York, Palgrave Macmillan, 2006.

STEEL 2004

Valerie STEEL, The Corset: A Cultural History, Yale, Yale University Press, 2004.

VALENTINI 2009

Ada VALENTINI, Food and Anthropology in the Early works of Matilde Serao, in "Quaderni d'italianistica», vol. 30, no. 2, 2009, pp. 130-145.

VANDEREYCKEN e VAN DETH 1995

Walter VANDEREYCKEN e Ron VAN DETH, Dalle sante ascetiche alle ragazze anoressiche. Il rifiuto del cibo nella storia, Milano, Raffaello Cortina Editore, 1995.

WALTER 2010

Natasha WALTER, Living Dolls: the Return of Sexism, London, Virago, 2010.

WILLSON 2008

Jacki Willson, The Happy Stripper: Pleasure and Politics of the New Burlesque, London and New York, I.B. Tauris \& Co, 2008.

WoOD 1995

Sharon WooD, Italian's Women Writing 1860-1994, London, The Athlone Press, 1995 . 